\title{
Effects of Refined Petroleum Hydrocarbon on Soil Physicochemical and Bacteriọlogical Characteristics
}

\author{
*OBIRE, O; NWAUBETA, $O$
}

Department Of Biological Sciences, Rivers State University OF Science and Technology, P.M.B. 5080 Port Harcourt Nigeria

\begin{abstract}
The physico-chemical and bacteriological characteristics of soils as influenced by the addition of $5 \%$ gasoline, kerosene and diesel oil hydrocarbons, were investigated. Soil for study was bulked from around a car park in Port Harcourt. Soil sampling was carried out at weekly intervals for four weeks and subsequently at monthly intervals for four months, between the months of March and July 1998. Physico-chemical parameters such as organic carbon, magnesium, and sodium increased from $1.48 \%$ to $2.46 \%: 0.60$ to $3.40 \mathrm{meg}$ $100 \mathrm{~g}^{-1}$ soil and 0.23 to $0.77 \mathrm{meg} 100 \mathrm{~g}^{-1}$ soil respectively. Nitrogen and phosphorous decreased from $0.15 \%$ to $0.07 \%$ and $35.1 \mathrm{ppm}$ to $10.88 \mathrm{pm}$ respectively while ammonium nitrate and nitrite were not affected in all soils. Calcium and potassium decreased beyond the control soil level in gasoline - contaminated soil after week 16. Counts of total viable aerobic heterotrophs ranged from $0.46 \times 10^{6} \mathrm{CFGg}^{-1}$ soil to $1.59 \times 10^{6} \mathrm{CFUg}^{-1}$ soil for the control soil; and from $0.56 \times 10^{6} \mathrm{CFUg}^{-1}$ to $2.40 \times 10^{6} \mathrm{CFUg}^{-1}$ soil for the hydrocarbon - contaminated soils. There was significant difference amongst treatments at $\mathrm{P}=1 \%$. @ JASEM
\end{abstract}

Petroleum is an extremely complex mixture of hydrocarbon and non - hydrocarbon Compounds (Atlas and Bartha, 1973, Chilingarian and Yen, 1978). Petroleum can be separated roughly into eight fractions or cuts based on carbon numbers because of the relationship between boiling point and molecular weight (Morrison and Boyd, 1966). The eight different fractions include natural gas, petroleum ether, Ligroin, (Light naphtha), gasoline, kerosene, gas oil (diesel) lubricating oil and asphalt (petroleum coke).

However, each fraction is still a very complicated mixture since each carbon number is represented by numerous isomers.

The increase in demand for petroleum resulted in an increase in their production, transportation and refining which in turn has resulted in gross pollution of the environment (Gutnick and Rosenberg, 1997).

The first major reported pollution incident from the Nigerian Oil Industry occurred on 19th July 1970, when Shell's Bomu - 11 oil well in Ogoni Division of Rivers State suddenly had a blow out impacting an estimated area of 607 hectares of agricultural land. Since then there has been reported cases of soil pollution by petroleum and petroleum products (Awobajo, 1981). The recent Jesse fire disaster in the Niger - delta area on 17th October 1998, caused by the leakage of a pipeline conveying refined petroleum is a case in point.

Today's society is increasingly concerned about soil degradation, the sustainability of soil productivity, and maintenance of biodiversity.

The environmental consequences of soil pollution include adverse effect on the soil microflora all of which assist in soil fertility (Odu, 1977; Torstensson et al., 1998).

*Corresponding author
Petroleum contamination of the soil results in the soil remaining unsuitable for crop growth and depending on the degree of contamination, the soil may remain unsuitable for crop growth for months or several years (Odu, 1997).

The size of the microbal biomass is generally considered to be important. The microbial biomass itself represents a considerable pool of nutrients, which is continuously shunted into growth cycles of micro - and macrophysics.

Consequently soils that maintain a high level of microbial biomas are capable of not only storing more nutrients, but also of cycling more nutrients through the system. (Torstensson et al, 1998)

To assess soil quality and fertility, indicators reflecting the physical, chemical and biological components of the soil are needed. Microorganisms being in intimate contact with the soil microenvironment are in many ways ideal as test organisms to monitor soil pollution.

In Nigeria there is scanty literature regarding the effect of petroleum and refined petroleum products on soil quality and on the occurrence of different bacterial species.

This study is aimed at providing information on the effect of refined petroleum hydrocarbons on soil physico-chemical properties and on the bacterial community of the soil. This was carried out by comparing the effect of gasoline, kerosene and diesel oil on the soil physico-chemical parameters on the bacterial population, and on the occurrences of different bacterial species in soil. 


\section{MATERIALS AND METHODS}

Peiroleum hydrocarbon contaminated soil was bulked from around a car park in Port Harcourt. Surface soil $(0$ to $15 \mathrm{~cm})$ was collected at random, air dried and passed through a $2 \mathrm{~mm}$ sieve and stored in a green house.

Petroleum hydrocarbon fractions (gasoline, kerosene and diesel oil) were collected from Total Petroleum Marketing Company and stored in sterile containers.

Soil physico-chemical parameters were analyzed before and after treatment with the different petroleum products. Particle size analysis was carried out using the hydrometer method (Boyoucos. 1951).

Soil Particle size

$\begin{array}{lll}\% \text { Clay } & = & 14 \% \\ \% \text { Silt } & = & 10.8 \% \\ \% \text { Sand } & = & 75 \%\end{array}$

Soil texture sandy loam.

Soil pH was determined using a pH meter 7020 (Electronic Instrument Ltd. Kent.) according to manufacture's instruction. The temperature of the soil samples was determined using a mercury thermometer.

Organic carbon was determined in accordance with titration method of Walkey and Black (1934). Total Nitrogen was determined by the Kiedahl digestion and steam distillation method (Black, 1965). Available phosphorous was determined by the method of Bary and Kurtz. (1945). Sodium and

Temperature readings ranged from $29^{\circ} \mathrm{C}$ to $30.8^{\circ} \mathrm{C}$ for control soil, $29^{\circ} \mathrm{C}$ to $31.4^{\circ} \mathrm{C}$ for gasoline contaminated soil, $30.9^{\circ} \mathrm{C}$ to $31.8^{\circ} \mathrm{C}$ for kerosene contaminated soil and $31.5^{\circ} \mathrm{C}$ to $32.5^{\circ} \mathrm{C}$ for diesel oil contaminated soil.

Except for the first week of the investigation when the temperature of the control soil was higher than that of gasoline contaminated soil, the temperatures of the hydrocarbon contaminated soils were generally higher than the temperatures of the control soil. The mean total temperature for the control soil was $29.9^{\circ} \mathrm{C}$ while those for the gasoline, kerosene and diesel oil contaminated soils were $30.5^{\circ} \mathrm{C} .31 .5^{\circ} \mathrm{C}$ and $32.0^{\circ} \mathrm{C}$ respectively.

The temperature values obtained for the different hydrocarbon contaminated soils during the investigation fall within the mesophilic range. This means that throughout the investigation period the temperature of the different hydrocarbon contaminated soils supported mesophilic organisms. The $\mathrm{pH}$ readings of the hydrocarbon contaminated soils and the control soil are as shown in Table 2 .

The $\mathrm{pH}$ values ranged from $\mathrm{pH} 5.7$ to 6.2 for the control soil while the values for the gasoline, The results of the physicochemical parameters for the control soils and the hydrocarbon-contaminated soils at the end of the investigations are shown in Table 3. potassium were determined using the flame photometer. Magnesium and calcium were determined using titration procedures.

The petroleum hydrocarbon treatments comprised of three different petroleum fractions (Gasoline, Kerosene and Diesel Oil). Treatment were applied at $0 \%$ and $5 \%$ levels. Bulked soil samples $(3.0 \mathrm{~kg})$ were transferred into separate perforated planting bags of surface area $531.14 \mathrm{~cm}$. The petroleum hydrocarbon contamination involved four treatments in a completely randomized design replicated three times .Soil sampling was carried out at weekly intervals for four weeks and subsequently at monthly intervals for four months between the months of March and July 1998.

The soils were moistened to $60 \%$ water holding capacity before treatment application, and on subsequent occasions as required.

Nutrient agar (Oxoid) was used for bacterial enumeration and isolation and was prepared in accordance with manufacturer's specification.

The method employed for the identification of the various isolates were in accordance with standard procedures (Holt et al., 1994).

\section{RESULTS AND DISCUSSION}

The temperature values of the hydrocarbon contaminated soils and the control are shown in Table

kerosene and diesel oil contaminated soils ranged from $\mathrm{pH} 5.9$ to 6.8 , $\mathrm{pH} 6.1$ to 6.5 . and $\mathrm{pH} 6.3$ to 6.8 respectively. The $\mathrm{pH}$ of the hydrocarbon contaminated soils were generally higher than the $\mathrm{pH}$ of the control soil. The total mean $\mathrm{pH}$ for the control soil is pH 5.9 while those for the gasoline, kerosene and diesel oil contaminated soils were $\mathrm{pH} 6.15, \mathrm{pH}$ 6.31 and $\mathrm{pH} 6.6$ respectively.

The $\mathrm{pH}$ values for the control soil and gasoline contaminated soil fluctuated between slightly acidic and moderately acidic, while the kerosene contaminated soil maintained slightly acidic pH throughout the investigation. The $\mathrm{pH}$ of the different hydrocarbon contaminated soils were tending from slightly acidic towards neutrality. These results are similar to the result obtained by Atlas (1981), who reported that neutral $\mathrm{pH}$ enabled biodegradation activity of bacteria in soils.

The present investigation has revealed the differences in soil characteristics (physico-chemical and hence the fertility and bacteriological status of the soils) as influenced by the presence of refined petroleum hydrocarbons. 
Effects of Refined Petroleum Hydrocarbon on...

Table 1. Temperature ("C) of Hydrocarbon Contaninated Soils

\begin{tabular}{|c|c|c|c|c|}
\hline \multicolumn{5}{|c|}{ SOIL TREATMENT } \\
\hline $\begin{array}{c}\text { Period } \\
\left(W_{e e k}\right)\end{array}$ & Control & Gasoline & Kerosene & $\begin{array}{c}\text { Diesel } \\
\text { Oil }\end{array}$ \\
\hline $\mathrm{W}_{1}$ & 30.8. & 30.5 & 31.7 & 31.9 \\
\hline $\mathrm{W}_{2}$ & 30 & 31.3 & 31.7 & 32.3 \\
\hline $\mathrm{W}_{3}$ & 30.2 & 31.2 & 31.5 & 31.7 \\
\hline $\mathrm{W}_{4}$ & .30 & 30 & 31.8 & 32 \\
\hline $\mathrm{W}_{8}$ & 29 & 31.4 & 31.5 & 32.5 \\
\hline $\mathrm{W}_{12}$ & 30.4 & 30.5 & 31.7 & 32.4 \\
\hline $\mathrm{W}_{16}$ & 29 & 29 & 30.9 & 31.5 \\
\hline TOTAL & 209.4 & 213.9 & 220.8 & 224.3 \\
\hline MEAN & 29.9 & 30.5 & 31.5 & 32.0 \\
\hline
\end{tabular}

Table 2: $\mathrm{pH}$ values of Hydrocarbon Contaminated Soils

\begin{tabular}{|c|c|c|c|c|}
\hline & \multicolumn{2}{|c|}{ SOIL TREATMENT } \\
\hline $\begin{array}{c}\text { Period } \\
(\text { Week })\end{array}$ & Control & Gasoline & Kerosene & Diesel Oil \\
\hline$W_{1}$ & 6.2 & 6.8 & 6.3 & 6.7 \\
\hline$W_{2}$ & 6.0 & 6.0 & 6.1 & 6.3 \\
\hline$W_{3}$ & 5.7 & 5.9 & 6.2 & 6.5 \\
\hline$W_{4}$ & 5.9 & 6.2 & 6.3 & 6.5 \\
\hline$W_{8}$ & 6.0 & 6.1 & 6.4 & 6.8 \\
\hline$W_{12}$ & 6.1 & 6.1 & 6.5 & 6.7 \\
\hline$W_{16}$ & 5.9 & 6.0 & 6.4 & 6.7 \\
\hline TOTAL & 41.8 & 43.1 & 44.5 & 46.2 \\
\hline MEAN & 5.97 & 6.15 & 6.31 & 6.6 \\
\hline
\end{tabular}

Values are means of three replicates

Table 3: Physico-chemical properties of the Hydrocarbon Contaminated Soils.

\begin{tabular}{|c|c|c|c|c|c|c|c|c|c|c|c|c|}
\hline \multirow{3}{*}{$\begin{array}{l}\text { Soil } \\
\text { Treatment }\end{array}$} & \multicolumn{4}{|c|}{ SOIL PARAMETERS } & \multirow[b]{2}{*}{$\mathbf{P}$} & \multirow[b]{2}{*}{$\mathrm{NH}_{4}+$} & \multirow{3}{*}{$\mathrm{NO}_{3}{ }^{-}$} & \multirow{3}{*}{$\mathrm{NO}_{2}^{-}$} & \multirow[b]{2}{*}{$c$} & \multirow[b]{2}{*}{$\mathrm{N}$} & \multirow[b]{2}{*}{$\mathrm{C} / \mathrm{N}$} & \multirow[b]{2}{*}{$\begin{array}{l}\text { Organic } \\
\text { Matter }\end{array}$} \\
\hline & $\mathrm{Ca}^{2+}$ & $\mathrm{Mg}^{2}$ & $\mathrm{~K}^{+}$ & $\mathrm{Na}^{\prime}$ & & & & & & & & \\
\hline & \multicolumn{4}{|c|}{ Meg $100 \mathrm{~g}^{-1}$ Soil } & \multicolumn{3}{|l|}{ PPM } & & & $(\%)$ & & \\
\hline Control 1 & 8.24 & 0.60 & 0.14 & 0.23 & 35.1 & 14 & 28 & 0 & 1.96 & 0.15 & 13.1 & 3.38 \\
\hline Control 2 & 6.70 & 1.50 & 0.18 & 0.49 & 24.25 & 12 & 28 & 2 & 1.66 & 02.07 & 23.7 & 2.86 \\
\hline $\begin{array}{l}\text { Gasoline } \\
(5 \%)\end{array}$ & 4.10 & 3.40 & 0.02 & 0.63 & 27.89 & 15 & 18 & 2 & 1.48 & 0.08 & 18.3 & 2.55 \\
\hline $\begin{array}{l}\text { Kerosene } \\
(5 \%)\end{array}$ & 7.70 & 0.90 & 0.53 & 0.77 & 10.88 & 15 & 28 & 4 & 1.85 & 0.11 & 16.8 & 3.18 \\
\hline $\begin{array}{l}\text { Diesel } \\
(5 \%)\end{array}$ & 8.40 & 2.00 & 0.21 & 0.45 & 24.04 & 15 & 14 & 2 & 2.46 & 0.08 & 30.8 & 4.24 \\
\hline
\end{tabular}

*Values are means of three replicates NOTE

Control 1 (Control soil at time O)

Control 2 (Control soil after 16 weeks) 
The values for calcium, magnesium, potassium, and sodium in the soils ranged from 4.10 to $8.40 \mathrm{meq}$ $100 \mathrm{~g}^{-1}$ soil, 0.06 to $3.4 \mathrm{meq} 100 \mathrm{~g}^{-1}$ soil and from 0.23 to 0.77 meq. $100 \mathrm{~g}^{-1}$ soil respectively. Available phosphorous ranged from 10.88 to $35.1 \mathrm{ppm}$; ammonia ranged from 14 to $28 \mathrm{ppm}$ and nitrite ranged from 0 to $4 \mathrm{ppm}$. Organic carbon, total nitrogen, carbon/ nitrogen $(c / \mathrm{N})$ and organic matter ranged from 1.48 to $2.46 \%$, 0.07 to $0.15 \%, 13.1$ to $30.8 \%$ and 2.55 to 4.28 respectively. Apart from the $\mathrm{pH}$, ammonia and total nitrogen which werc gencrally higher in the hydrocarbon contaminated soils than in the control soil, the different hydrocarbons exhibited varying effects (i.e. increasing or decreasing) on the other soil parameters.

Magnesium and sodium increased in all petroleum hydrocarbon treated soils, including the control soil at the end of the investigation as compared to the control soil at the on-set of the investigation. However, magnesium was lower in kerosene treated soil than in the control soil after week 16. Sodium value was lower in diesel oil treated soil than in the control soil after week 16. Except for the diesel oil contaminated soil, calcium decreased in controls, gasoline and kerosene contaminated soils as compared to the control at the on-set of the investigation. Calcium value was lower for gasoline treated soil than in the control soil after week 16. Except for the gasoline contaminated soil, potassium values were higher in the petroleum contaminated soils than for the control soils.

The value obtained for magnesium and potassium in the control soil at the on-set of the investigation was $8.24 \mathrm{meq} 100 \mathrm{~g}^{-1}$ soil and $0.14 \mathrm{meq} 100 \mathrm{~g}^{-1}$ soil respectively. At the end of the investigation, magnesium values obtained for kerosene contaminated soil and control soil, and the potassium value obtained for gasoline soil were far below the value reported by Odu et al., (1985) as being good enough to maintain soil fertility in Nigerian soils.
Available phosphorous in the soil at the onset of the investigation was $35.1 \mathrm{ppm}$ but decreased in all hydrocarbon treated soils, including the control at the end of the investigation. The available phosphorous for the gasoline, diesel oil and control soils after week 16 decreased as compared to the control at the on-set of the investigation but was still within the moderate range for soil fertility as reported by Odu et al., (1985). Kerosene treatment depressed soil available phosphorous beyond the level considered moderate for soil fertility.

Total nitrogen was depressed in all soils. Amadi et al., (1993) also reported nitrogen depression in soils contaminated with petroleum hydrocarbons. Before contamination of soils with different refined petroleum hydrocarbons, the values obtained for total nitrogen was $0.15 \%$ but by the end of the investigation, total nitrogen in all the soil were below $0.15 \%$. Odu et $a l$., (1985) reported that total nitrogen value of less than $0.1 \%$ is considered low for soils. Amongst experimental soils, after week 16 only kerosene contaminated soil had total nitrogen value of about $0.1 \%$.

The decrease in available phosphorous and total nitrogen as reported in this investigation could be due to the fact that available phosphorous and total nitrogen were essential for biodegradation. (Atlas et al., 1978). So it could be that as hydrocarbon biodegradation proceeds available phosphorous and total nitrogen were being exhausted. The mineral nitrogen at the on-set and at the end of investigation fall within the moderate values acceptable for normal soils. In other words mineral nitrogen was not affected negatively in the petroleum hydrocarbon contaminated soils at the end of the investigation. The total aerobic heterotrophic bacteria counts for the control soil and the hydrocarbon contaminated soils are shown in Table 4.

Table 4: Counts of Total Acrobic Hetcrotrophic Bacteria in the Hudrocarbon Contaminated Soils $\left(810^{6} \mathrm{CFUg}^{-1}\right.$ Soils)

\begin{tabular}{|c|c|c|c|c|}
\hline \multirow[b]{2}{*}{$\begin{array}{l}\text { Period } \\
\text { (Week) }\end{array}$} & \multicolumn{3}{|c|}{ SOIL TREATMENT } & \multirow[b]{2}{*}{ Diesel } \\
\hline & Control & Gasoline & Kerosene & \\
\hline$w_{1}$ & 1.59 & 1.36 & 1.22 & 0.90 \\
\hline$W_{2}$ & 1.54 & 2.10 & 2.40 & 1.14 \\
\hline $\mathrm{w}_{3}$ & 1.30 & 1.80 & 2.22 & 1.00 \\
\hline $\mathrm{W}_{4}$ & 0.55 & 0.80 & 0.83 & 0.96 \\
\hline$W_{8}$ & 0.84 & 0.64 & 0.75 & 0.77 \\
\hline$W_{12}$ & 0.55 & 0.58 & 0.98 & 1.04 \\
\hline$W_{16}$ & 0.46 & 0.56 & 1.04 & 1.15 \\
\hline Total & 6.85 & 7.85 & 9.44 & 6.97 \\
\hline Mean & 0.97 & 1.12 & 1.34 & 0.99 \\
\hline
\end{tabular}


The total aerobic heterotrophic bacterial counts for the control soil ranged from $0.46 \times 10^{6} \mathrm{CFUg}^{-1}$ soil to 1.59 $\times 10^{6} \mathrm{CFUg}^{-1}$ soil while counts for gasoline, kerosene and diesel oil contaminated soils ranged from $0.56 \mathrm{x}$ $10^{6} \mathrm{CFUg}^{-1}$ soil to $2.10 \times 10^{6} \mathrm{CFU}^{-1}$ soil, $0.75 \times 10^{6}$ $\mathrm{CFUg}^{-1}$ soil to $2.40 \times 10^{6} \mathrm{CFUg}^{-1}$ soil and $0.77 \times 10^{6}$ CFUg $^{-1}$ to $1.15 \times 10^{6} \mathrm{CFUg}^{-1}$ soil respectively. The total mean count for the control soil was $0.97 \times 10^{6}$ $\mathrm{CFUg}^{-1}$ soil while those for the gasoline, kerosene and diesel oil contaminated soils were $1.12 \times 10^{6} \mathrm{CFUg}^{-1}$ soil. $1.34 \times 10^{6} \mathrm{CFUg}^{-1}$ soil and $0.99 \times 10^{6} \mathrm{CFUg}^{-1}$ soil respectively. The numbers of bacteria increased from week 1 to week 8 and then slowly decreased. Except for week 8, the gasoline-contaminated soil, kerosene- contaminated soil and diesel oil contaminated soil supported more bacterial growth than the control soil. The cumulative bacterial counts in the treated soils was in the order of kerosene > Gasoline $>$ Diesel $>$ Control soil.

The organisms could have exhausted the available nutrient supplies present in the system. It could also be that there was introduction of toxic metabolites into the system, which was responsible for the decreased growth phase of the bacteria. Amadi and Odu (1993) reported an initial gradual increase in bacterial population following the application of petroleum hydrocarbon but a decline as the biodegradation progressed.

Analysis of variance carried out on the total viable aerobic heterotrophic bacteria showed a significant difference at $P=1 \%$. This result showed that the addition of $5 \%$ of the petroleum hydrocarbons, actually enhanced the proliferation of the heterotrophic bacteria.

Although a lot of research has been carried out on microbial degradation of petroleum hydrocarbons, there is no literature on the succession of heterotrophic bacteria in hydrocarbon-contaminated soils.

The effect of refined petroleum hydrocarbon on the occurrence of aerobic heterophic bacteria in soil is as shown in Table 5.

Table 5: Bacterial species isolated and their occurrence in the control and refined petroleum

\begin{tabular}{|c|c|c|c|c|}
\hline Soil Trealment/ Period of & Control & Gasoline & 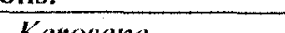 & \\
\hline$W_{1}$ & $\begin{array}{l}\text { Bacillus sp. } \\
\text { Klebsiella sp. }\end{array}$ & $\begin{array}{l}\text { E. coli } \\
\text { P. aeruginosa }\end{array}$ & Bacillus sp. & $\begin{array}{l}\text { Micrococcus roseus. } \\
\text { P. aeruginosa }\end{array}$ \\
\hline $\mathrm{W}_{2}$ & $\begin{array}{l}\text { Flavobacterium sp } \\
\text { P. aeruginosa }\end{array}$ & $\begin{array}{l}\text { E. coli } \\
\text { Proteus mirabilis } P .\end{array}$ & P. aeruginos & $\begin{array}{l}\text { Micrococcus luteus } P \text {. } \\
\text { aeruginosa }\end{array}$ \\
\hline $\mathrm{W}_{3}$ & $\begin{array}{l}\text { Actinomyces } \\
\text { Staph aureus }\end{array}$ & $\begin{array}{l}\text { aeruginosa } \\
\text { Bacillus sp Serratia } \\
\text { marcescens }\end{array}$ & $\begin{array}{l}\text { E. coli Proteus } \\
\text { mirabilis }\end{array}$ & $\begin{array}{l}\text { Klebsiella sp } \\
\text { Proteus mirabilis }\end{array}$ \\
\hline$W_{4}$ & Bacillus sp & Bacillus sp & Bacillus sp & Bacillus sp \\
\hline $\mathrm{W}_{8}$ & $\begin{array}{l}\text { Flavobacterium } s p \\
\text { Klebsiella } s p\end{array}$ & $P$. aeruginosa & P. aeruginosa & P. aeruginosa \\
\hline$W_{12}$ & Alealigenes faecalis & $\begin{array}{l}\text { Bacillus sp Klebsiella } \\
\text { sp }\end{array}$ & Staph aureus & Micrococcus luteus \\
\hline$W_{16}$ & $\begin{array}{l}\text { Arthrobacter } \quad s p \\
\text { Bacillus sp }\end{array}$ & Bacilluss sp & E. coli & $P$. aeruginosa \\
\hline
\end{tabular}

The heterotrophic bacterial species isolated from control soil in the first week of investigation are Bacillus $s p$; and Klebsella sp for the control soil, while for the hydrocarbon contaminated soils the isolates include Escherichia coli. Pseudomonas aeruginosa; Bacillus sp and Micrococcus roseus. These bacterial species were not rendered dormant or eliminated by the presence of the added hydrocarbon fractions.

In Week 2, as biodegradation proceeded, in control soil Pseudomonas aeruginosa and Flavobacterium were found. These bacterial species have entered the growth phase in the control soil, while Pseudomonas aeruginosa; Escherichia coli; Proteus mirabilis and Micrococcus luteus were present in the hydrocarbon contaminated soils. Pseudomonas aeruginosa and Escherichia coli persisted in the hydrocarbon contaminated soils. This could he due to availabilitv of utilizable nutrients.
By week 3 in the control soil Actinomyces and Staphylococcus aureus entered the growth phase, although they have been dormant from the on-set of the investigation. For the hydrocarbon contaminated soils. Proteus mirabilis, Escherichia coil, Serratia marcescens and Klebsiella were in their growth phase. Proteus mirabilis and Escherichia coli persisted from week 2. This shows that the presence of the hydrocarbon treatment must have stimulated the proliferation of these organisms. At week 4 Bacillus sp thrived in both the control soil and in all the hydrocarbon contaminated soils, although it has previously declined in the control soil. It must have been stimulated to proliferate due to the presence of some utilizable products of hydrocarbon degradation.

Flavobacterium and Klebsiella entered the growth phase in control soil, while Pseudomonas aeruginisa thrived in all hudrocarbon contaminated soils bv week 8 . This 
shows that the presence of the added hydrocarbons to the soil must have stimulated the proliferation of the organisms.

At week 12, Bacillus and Alcaligenes faecalis entered the growth phase in the control soil, while for the hydrocarbon contaminated soil, Klebsiella, Bacillus, Staphylococcus aureus, Micrococcus luteus are reactivated and thrived in the hydrocarbon contaminated soils, although Alcaligenes faecalis have been dormant from the on-set of the investigation.

Bacillus persisted in the control soil till week 16, while Arthrobacter which has been dormant from the on set entered the growth phase.

\section{CONCLUSION}

This investigation has revealed that refined petroleum products do have increasing or decreasing effects on soil physico-chemical parameters. Parameters such as nitrogen and phosphorous decreased in all hydrocarboncontaminated soils. Phosphorous decreased but not beyond the quantity that could help to maintain soil fertility in Nigerian soils except in kerosene contaminated soil. Except in kerosene - contaminated soils, nitrogen levels decreased beyond soil fertility levels in the control and hydrocarbon - contaminated soils. Organic carbon, sodium and magnesium increased in contents while ammonium, nitrate and nitrite were not affected.

There was no significant difference among control and hydrocarbon - contaminated soils for the total aerobic heterotrophs at $5 \%$ probability level. This study also confirms that microbial numbers are stimulated on application of petroleum hydrocarbons and gradually declined as the lighter fractions are exhausted.

\section{REFERENCES}

Amadi, A. and C. T. I. Odu, 1993, Effect of simulated chemical Demulsifer (Separal NF. 36 and Servo (.6602) contamination of soil, on carbondioxide Evolution and shifts in Microbial Population in a fresh water mangrove Ecosystemm International Journal of Biochemphysics 2:1-2pp. $97-99$.

Atlas, R. M,. A. P. Sextone, O. Gustin . O. Miller. P. Linkins and K. Everett, 1978. Biodegradation of crude oil by Tundra soil Microorganisms Proceedings of the $4^{\text {th }}$ International Biodegradation Symposium Applied Science Publs. Ltd. pp.21 - 26.

Atlas, R. M. 1981. Microbial Degradation of
Petroleum Hydrocarbons. An Environmental Perspective, Microbial Rev. 45: 180:209.

Awobajo. A. O. (1981). An analysis of oil spill incidents in Nigeria. Proceedings of National Seminar on Petroleum Industries and Nigerian Environment. Warri pp.57-63.

Black. C. A. 1965. Methods of Soil Analyses. Agronomy No. 9. American Society of Agronomy. Madison Wineonsin.

Bouyoucos, G.'H. 1951. A Recalibration of the Hydrometer for making Mechanical analysis of Soils. Agron. J. 43: $434-438$.

Bray, R. T.H and I. T. Kurtz. 1945 Soil_Science 59:39.

Chilingerian. G. V. and T. F. Yen. (1978).

Organic matter and origin of oil and Tar Sand. In: G. V. Chiligerian and T. F. Yen (Eds.) Bitumens, asphalts and Tar Sands. Developments in Petroleum Science. 7 Elsevier scientific Pub. Co. New York.

Gutnick. D. L., and E. Rosenberg (1977) Oil tankers and pollution" A microbiological approach Annu. Rev. Microbiol 31:379 - 396

Holt. J. G,. N. R. Krieg. P. H. A. Sneath. J. T. Staley. and S. T. Williams 1994. Bergey's Manual of Determinative Bacteriology. $9^{\text {th }} \mathrm{Ed}$. Williams and Wilkins. pp. $71-561$.

Morrison. R. T. and R. N. Boyd. (1966). Organic Chemisty (2nd Ed.). Allyn and Bacon, Inc., Boston. USA.

Torstensson. L. Mikael Pell and Bo Stenberg. 1998. Need of a Strategy for Evaluation of Arable Soil Quality AMBIO 27 (1).4- 7.

Odu. C. T. L., O. F. Esuruoso. L. C. Nwoboshi and J. A. Oguwale, 1985. Environmental Study of the Nig. Agip. Oil Company Operational Area. Soil and Fresh Water Vegatation. Union Graft, Milan pp. 22 25 .

Walkey. A. and 1. A. Black. 1934 Methods of Soil analysis. Soil Science. 37:29. 